\title{
Effect of four herbicides on the establishment and forage yield of stargrass in Puerto Rico'
}

\author{
María de L. Lugo ${ }^{2}$, Li C. Liu ${ }^{3}$, and Carlos E. Ortiz ${ }^{4}$
}

\begin{abstract}
An experiment was performed at the AES-UPR Gurabo Substation to evaluate atrazine, simazine, diuron, and tebuthiuron for preemergence control of weeds in a stargrass pasture. Tebuthiuron at $3.36 \mathrm{~kg} \mathrm{a.i./ha} \mathrm{was}$ the most effective, and tebuthiuron at $1.68 \mathrm{~kg}$ a.i./ha was the second most effective. The remaining herbicides also provided satisfactory weed control. At $3.36 \mathrm{~kg}$ a.i. $/$ ha, tebuthiuron was somewhat phytotoxic to stargrass, but less so at $1.68 \mathrm{~kg} \mathrm{a.i./ha.} \mathrm{None} \mathrm{of} \mathrm{the} \mathrm{other} \mathrm{herbicides} \mathrm{produced} \mathrm{severe}$ stargrass injury. Stargrass yield was not affected by any of the herbicides. Crude protein content of stargrass was not affected by any herbicide tested.
\end{abstract}

\section{RESUMEN}

Efecto de cuatro yerbicidas sobre el establecimiento y el rendimiento en forraje de la yerba estrella

Se realizó un experimento de campo en un suelo arcilloso de la serie Mabí en la subestación de Gurabo para evaluar atrazine, simazine, diuron y tebutiuron para reprimir las malezas en el pasto estrella. Los efectos de estos herbicidas y sus concentraciones se compararon con testigos desyerbado a mano y sin desyerbar. El tratamiento que mejor reprimió las malezas fue tebutiuron a $3.36 \mathrm{~kg}$ p.a./ha; le seguió el mismo herbicida a $1.68 \mathrm{~kg}$. p.a./ha. Simazine a la dosis de 2.24 y $4.48 \mathrm{~kg}$. p.a./ha. también las reprimió bien. Tebutiuron a la dosis de $3,36 \mathrm{~kg}$. p.a./ha. le causó fitotoxicidad al pasto estrella; sin embargo, el mismo herbicida a $1.68 \mathrm{~kg}$. p.a./ha. le fue menos fitotóxioo. Ninguno de los otros herbicidas le causó daño severo de fitotoxicidad al pasto. El rendimiento de la yerba estrella no se afectó significativamente por ningún herbicida o dosis. Ninguno de los tratamientos de herbicidas causó cambios significativos en el contenido en proteína bruta de la yerba estrella.

\section{INTRODUCTION}

Stargrass (Cynodon nlemfuensis) is becoming a major pasture grass in Puerto Rico. Caro-Costas et al. (2) reported that stargrass pasture produced about 30 percent higher gains in cattle weight than pangola grass pasture under conditions typical of the humid mountain region of Puerto Rico. Stargrass outyielded pangola grass in all grazing experiments conducted by Vicente et al. (7). Although stargrass produces excellent forage yields in Puerto Rico's humid mountain region, it is subject to severe weed competition during its early establishment stage.

\footnotetext{
'Manuscript submitted to Editorial Board 6 October 1988.

${ }^{2}$ Research Assistant.

${ }^{3}$ Plant Physiologist.

${ }^{4}$ Research assistant.
} 
Past insular weed control research has concentrated on pangola pastures. Spain and Sotomayor (6) reported that simazine and atrazine at rates of 1.8 to $7.2 \mathrm{~kg} /$ ha gave effective weed control during establishment of pangola grass. However, preference was directed to atrazine by virtue of its less-pronounced phytotoxicity. Excellent control of broadleaf weeds in two pangola grass pastures was reported by González (3). He employed Tordon 101 mixture and dicamba /2,4-D mixtures. In a subsequent study, González (4) found that glyphosate controled cortadora grass in pangolaguinea pastures and in native grass pastures. The only study on preemergence control of weeds in stargrass was performed by Rodríguez (5). He found that simazine was the most favorable compound. It effected a material increase in the forage yield and crude protein content of stargrass. He also found that hexazinone was the best postemergence herbicide. Its use allowed a greater yield than the yield of the handweeded check in terms of forage and its crude protein content.

Certain preemergence herbicides have recently become available. Research on their use for weed control in Puerto Rican pasture should be intensified. The present study was initiated to evaluate atrazine [6chloro-N-ethyl-N-(1-methyl ethyl) 1,3,5 triazine 2,4-diamine]; simazine (6-chloro-N, N-diethyl-1,3,5 triazine-2,4-diamine); diuron [N-(3,4dichlorophenyl) $\mathrm{N}, \mathrm{N}$-dimethylurea]; and tebuthiuron $\{\mathrm{N}-5-(1,1$ dimethylethyl)-1,3,4-thiadizol-2yl]-N,N-dimethylurea\} for preemergence control of weeds in a stargrass pasture.

\section{MATERIALS AND METHODS}

An experiment was performed at the AES-UPR Gurabo Substation in February 1988. The soil series is a Mabí clay (Vertic Eutropepts). The site was plowed and disc-harrowed twice. Each plot was $3.05 \mathrm{~m}$ wide and $3.05 \mathrm{~m}$ long and consisted of four rows spaced $70 \mathrm{~cm}$ apart. Stolons of stargrass (Cynodon nlemfuensis) were planted in 15-cm deep furrows. A blank row separated individual plots.

Test herbicides were applied as aqueous sprays over the planted stargrass one day after planting. A knapsack sprayer equipped with 8003 Teejet tips was used. These treatments included atrazine (AATREX) at 2.24 and $4.48 \mathrm{~kg}$ a.i./ha, simazine (PRINCEP) at 2.24 and $4.48 \mathrm{~kg}$ a.i./ha, diuron (KARMEX) at 1.68 and $3.36 \mathrm{~kg}$ a.i./ha, and tebuthiuron (SPIKE) at 1.68 and $3.36 \mathrm{~kg}$ ai. $/ \mathrm{ha}$. The spray volume was approximately 1,076 1/ha. There were both non-weeded and handweeded controls. The treatments were arranged in a randomized complete block design with four replications of each treatment.

A 15-5-10 commercial fertilizer was banded at the rate of 0.55 metric ton/ha 3 weeks after planting. Weeds were removed manually from handweeded control plots at 4 and 8 weeks after planting. Weed control and phytotoxicity to stargrass were rated visually at 4 and 8 weeks after 
herbicide application. Both stargrass and weeds were harvested 84 days after planting and green weights were recorded. Stargrasss was analyzed for crude protein content. Oven-dry weights of both stargrass and weeds were recorded. Crude protein was determined in accordance with wet washing procedure (1).

The recorded data were submitted to statistical analysis of variance. Mean values were compared in accordance with Duncan's Multiple Range Test.

\section{RESULTS AND DISCUSSION}

The predominant weed species present in decreasing order of abundance: para grass [Brachiaria purpurascens (Raddi) Henr.], black nightshade [Solanum americanum (Jacq.) Edmonds], spreading dayflower (Commelina diffusa Burm. f), Indian heliotrope (Heliotropium indicum L.), cortadora grass (Paspalun millegrana Sohrad.), crabgrass [Digitaria sanguinalis (L.) Scop.], goose grass [Eleusine indica (L.) Gaertn.], spurge (Euphorbia heterophylla L.), jungle rice [Echinochloa colona (L.) Link.], purple nutsedge (Cyperus rotundus L.), waterprimrose [Ludwigia erecta L.) H. Hara], Mexican weed [Caperona palustris (L.) St. Hil.], purslane (Portulaca oleracea L), and niruri (Phylanthus niruri L.). Among these, purple nutsedge, para grass and cortadora grass were only poorly controlled by all four herbicides.

Weed-control ratings at 4 weeks after herbicide application indicate that tebuthiuron gave the most effective weed control (table 1). Both the 1.68 and $3.36 \mathrm{~kg}$ a.i./ha rates were effective. Satisfactory control was also attained with simazine $(4.48 \mathrm{~kg}$ a.i./ha), atrazine $(2.24$ and $4.48 \mathrm{~kg}$ a.i./ha), and diuron (2.24 and $4.48 \mathrm{~kg}$ a.i./ha). Ratings taken at 8 weeks

TABLE 1.-Weed control and phytotoxicity ratings at 4 and 8 weels after herbicide application

\begin{tabular}{|c|c|c|c|c|c|}
\hline \multirow[b]{2}{*}{ Treatments } & \multirow[b]{2}{*}{ Rate } & \multicolumn{2}{|c|}{ Weed control at } & \multicolumn{2}{|c|}{ Phytotoxicity at } \\
\hline & & 4 week & 8 week & 4 week & 8 week \\
\hline & (kga.i./ha) & $\%$ & $\%$ & $\%$ & $\%$ \\
\hline Atrazine & 2.24 & $88 a b^{1}$ & $51 c^{1}$ & $10 \mathrm{~cd}^{1}$ & $0 \mathrm{~b}^{1}$ \\
\hline Atrazine & 4.48 & $89 a b$ & $66 \mathrm{abc}$ & $36 \mathrm{ab}$ & $4 \mathrm{~b}$ \\
\hline Simazine & 2.24 & $83 \mathrm{bc}$ & $67 \mathrm{abc}$ & $3 d$ & $4 \mathrm{~b}$ \\
\hline Simazine & 4.48 & $90 \mathrm{ab}$ & $72 \mathrm{abc}$ & $11 \mathrm{~cd}$ & $0 \mathrm{~b}$ \\
\hline Tebuthiuron & 1.68 & $91 \mathrm{a}$ & $80 \mathrm{ab}$ & $23 \mathrm{bc}$ & $0 \mathrm{~b}$ \\
\hline Tebuthiuron & 3.36 & $93 \mathrm{a}$ & $82 \mathrm{ab}$ & $52 \mathrm{a}$ & $26 a$ \\
\hline Diuron & 1.68 & $75 \mathrm{c}$ & $62 \mathrm{bc}$ & $9 \mathrm{~cd}$ & $1 \mathrm{~b}$ \\
\hline Diuron & 3.36 & $80 \mathrm{c}$ & $69 \mathrm{abc}$ & $10 \mathrm{~cd}$ & $2 \mathrm{~b}$ \\
\hline Nonweeded & - & $0 \mathrm{~d}$ & $0.0 \mathrm{~d}$ & $0 d$ & $0 \mathrm{~b}$ \\
\hline Hand-weeded & - & $100 \mathrm{a}$ & $90 a$ & $0 \mathrm{~d}$ & $0 \mathrm{~b}$ \\
\hline
\end{tabular}

'Means followed by the same letter or letters do not differ significantly at the 0.05 probability level. 
after herbicide application indicate that tebuthiuron at both rates appeared to give better weed control than did atrazine $(2.24 \mathrm{~kg} / \mathrm{ha})$. In terms of herbicide phytotoxicity to stargrass, tebuthiuron was the most injurious compound tested (table 1).

With reference to harvested green weights, weed production was lowest in the handweeded treatment (table 2). Tebuthiuron at both rates, together with six other herbicide treatments, was effective in repressing weed growth. Similar trends were evident for weed dry matter yield (table 2).

With reference to the stargrass crop, highest fresh weights were produced by plots treated with tebuthiuron (table 2). However, there were no statistically-significant differences among herbicide treatments in general. Stargrass dry matter production was obtained from handweeded control plots. There was no statistically significant correlation between yield and phytotoxicity rating data. None of the herbicide treatments affected the crude protein content of stargrass.

Our findings that the initial crop phytotoxicity of atrazine is greater than that of simazine is not in agreement with findings by Spain and Sotomayor (6). This discrepancy is attributed to their use of pasture species other than stargrass. An additional finding that none of the present herbicide treatments produced crude protein losses is not consistent with the finding of Rodríguez (5) working with simazine-treated stargrass. No adequate explanation for this inconsistency can be established.

TABLE 2.-Dry and fresh weights of weeds and stargrass, and crude protein content of stargrass

\begin{tabular}{|c|c|c|c|c|c|c|}
\hline \multirow[b]{2}{*}{ Treatment } & \multirow[b]{2}{*}{ Rate } & \multicolumn{2}{|c|}{ Weeds } & \multicolumn{2}{|c|}{ Stargrass } & \multirow[b]{2}{*}{$\begin{array}{l}\text { Crude } \\
\text { proteir }\end{array}$} \\
\hline & & $\begin{array}{l}\text { Fresh } \\
\text { weight }\end{array}$ & $\begin{array}{c}\text { Dry } \\
\text { weight }\end{array}$ & $\begin{array}{l}\text { Fresh } \\
\text { weight }\end{array}$ & $\begin{array}{l}\text { Dry } \\
\text { Dry }\end{array}$ & \\
\hline & kg a.i.ha & $\mathrm{kg} / \mathrm{ha}$ & $\mathrm{kg} / \mathrm{ha}$ & $\mathrm{kg} / \mathrm{ha}$ & $\mathrm{kg} / \mathrm{ha}$ & $\%$ \\
\hline Atrazine & 2.24 & $15,414 a b c^{1}$ & $4,305 b c^{1}$ & $17,695 \mathrm{a}^{2}$ & $3,797 \mathrm{ab}^{1}$ & $12 \mathrm{a}^{1}$ \\
\hline Atrazine & 4.48 & $16,275 a b$ & 4,649 bc & $12,399 \mathrm{ab}$ & $3,035 \mathrm{ab}$ & $12 \mathrm{a}$ \\
\hline Simazine & 2.24 & $15,026 \mathrm{abc}$ & $4,435 \mathrm{bc}$ & $14,682 \mathrm{ab}$ & $3,810 a b$ & $11 \mathrm{a}$ \\
\hline Simazine & 4.48 & 15,844 abe & $2,153 \mathrm{~cd}$ & $17,050 \mathrm{a}$ & $3,961 \mathrm{ab}$ & $13 \mathrm{a}$ \\
\hline Tebuthiuron & 1.68 & 7,491 be & $1,507 \mathrm{ed}$ & $18,212 \mathrm{a}$ & $3,616 \mathrm{ab}$ & $13 \mathrm{a}$ \\
\hline Tebuthiuron & 3.36 & 7,405 bc & $1,851 \mathrm{~cd}$ & $15,112 \mathrm{ab}$ & $2,820 a b$ & $13 \mathrm{a}$ \\
\hline Diuron & 1.68 & $13,605 \mathrm{abc}$ & $4,305 \mathrm{bc}$ & $13,734 \mathrm{ab}$ & $3,134 \mathrm{ab}$ & $10 \mathrm{a}$ \\
\hline Diuron & 3.36 & $16,791 \mathrm{ab}$ & $5,381 \mathrm{~b}$ & $13,261 \mathrm{ab}$ & $3,152 \mathrm{ab}$ & $12 a$ \\
\hline Nonweeded & - & 23,852 a & $9,472 \mathrm{a}$ & $6,458 \mathrm{~b}$ & $1,550 \mathrm{~b}$ & $10 \mathrm{a}$ \\
\hline Hand-weeded & - & $3,444 \mathrm{c}$ & $775 \mathrm{~d}$ & $17,437 \mathrm{a}$ & $4,241 \mathrm{a}$ & $11 \mathrm{a}$ \\
\hline
\end{tabular}

${ }^{\prime}$ Means followed by the same letter or letters do not differ significantly at the 0.05 probability level. 


\section{LITERATURE CITED}

1. Anonymous, 1978. Individual/simultaneous determination of nitrogen and/or phosphorus in $B$ D acid digests. Industrial method No. 329-74 W/B, p. 1-8.

2. Caro-Costas, R., F. Abruña and J. Vicente-Chandler, 1972. Comparison of heavily fertilized pangola and stargrass pastures in terms of beef production and carrying capacity in the humid mountain region of Puerto Rico. J. Agric. Univ. P. R. 56: 104-09.

3. González-Ibáñez, J., 1984. Control of resistant broadleaf species in Puerto Rican pastures using mixtures of 2,4-D with picloram and dicamba. J. Agric. Univ. P. R. 61: 326-31.

4. - 1984. Glyphosate for weed control in Puerto Rican pastures. J. Agric. Univ. P. R. 68: 289-96.

5. Rodriguez-Domínguez, P., 1982. Control químico de malezas en cultivo de yerba estrella. Thesis Maestría Univ. P. R., Mayagüez.

6. Spain, G. L. and A. Sotomayor-Ríos, 1976. Effect of two triazine compounds on the establishment and forage yield of pangola grass. J. Agric. Univ. P. R. 60: 201-06.

7. Vicente-Chandler, J., F. Abruña, R. Caro-Costas and S. Silva, 1983. Producción y utilización intensiva de las forrajeras en Puerto Rico. Esta. Exp. Agric., Univ. P. R., Bol. 271. 